\title{
Residual neurobehavioural effects associated with chronic exposure to mercury vapour
}

\author{
Reiko Kishi, Rikuo Doi, Yasuma Fukuchi, Hiroshi Satoh, Tsuyoshi Satoh, Akio Ono, \\ Fumio Moriwaka, Kunio Tashiro, Naohiko Takahata, Harumi Sasatani, \\ Higashi Shirakashi, Tersuhiro Kamada, Katsuo Nakagawa
}

\begin{abstract}
To find the residual effects of long term exposure to mercury vapour, neurobehavioural tests were given to ex-mercury miners about 18 years after the end of mercury exposure. Seventy six male exmercury miners who had been exposed to high concentrations of mercury vapour (over $1.0 \mathrm{mg} / \mathrm{m}^{3}$ ) and with a history of mercury intoxication were compared with controls matched for age (within 3 years), sex, and education. Although the extent of the workers' symptoms caused by mercury poisoning, termed erethismus merculialis, decreased considerably after the end of exposure, matched paired comparison showed that performances of motor coordination, simple reaction time, and short term memory had deteriorated significantly in the exposed group. Multiple linear regression analysis of exposure variables with neurological examination measures showed positive correlations between poorer neurological performance and variables related to mercury exposure. Thus the duration of exposure correlated with poorer performance of hand-eye coordination, tapping, and a colour card reading test. Job categories classified by exposure to mercury also had a significant negative correlation with these performances. The period of years after the end of exposure hada significant correlation with better performance of reaction time and digit span. On the other hand, the history of intoxication itself had no significant correlation with any ofthe current neurobehavioural performances. These results suggest that there are slight but persistent effects on neurobehavioural function, especially on motor coordination, among mercury miners even more than 10 years after the end of exposure.
\end{abstract}

(Occup Environ Med 1994;51:35-41)

Chronic inorganic mercury poisoning in humans is characterised by the development of tremor, psychic disturbances, and altered behaviour, the last two of which are known together as erethismus mercurialis. ${ }^{1}$ According to published reports, the neurobehavioural effects of mercury vapour are categorised into four groups: (1) disturbances of the motor system, such as fine tremor of the extremities and poor psychomotor performance, ${ }^{2-4}$ (2) deterioration of intellectual capacity, such as memory disturbances and poor verbal intelligence, ${ }^{5-10}$ (3) alterations of the emotional state such as depressive mood, irritability, and listlessness, ${ }^{5}$ and (4) peripheral neurotoxicity, such as polyneuropathy with prolonged motor and sensory nerve conduction. ${ }^{11-14}$

There are, however, only a limited number of reports on neurobehavioural effects after the end of exposure. Albers et al recently examined 247 ex-workers who had been exposed to mercury vapour for 20 to 35 years previously to identify potential exposure related neurological abnormalities. ${ }^{15}$ They found that subjects with a history of peak urinary mercury concentrations above $0.6 \mathrm{mg} / \mathrm{l}$ showed significantly decreased strength, decreased coordination, increased tremor, decreased sensation, and increased prevalence of Babinski and snout reflexes when compared with the subjects with lower exposure. In our study we have surveyed symptoms and neurobehavioural performances of ex-mercury miners about 18 years after the end of exposure to mercury to find if there were any adverse residual effects of long term exposure to mercury vapour.

\section{Methods}

STUDY POPULATIONS

The subjects were ex-miners of a mercury mine in Hokkaido, Japan, which started mining in 1939 and closed in 1970. About 1000 men were engaged in mining at the plant before 1945, (the end of the second world war), whereas 517 men and 143 women worked there in 1947. The number of employees then gradually decreased to 361 men and 64 women in 1969.

Work processes and working conditions in the mine have been described previously by the industrial physician. ${ }^{16}$ The atmospheric mercury concentration was usually over $1.0 \mathrm{mg} / \mathrm{m}^{3}$ - for example, $1.9-3.3 \mathrm{mg}$ at the pit face and $1.5 \mathrm{mg}$ at the over chute. The mean working time of these workers was 378 minutes each day. Unfortunately the exact medical records with the monthly results of urinary mercury analyses have been lost. Mercury concentrations in urine at the time of diagnoses were high-for example, $72 \cdot 4 \%$ of cases (60 of 83 patients) showed urinary mercury concentrations of $500-2000 \mu \mathrm{g} / \mathrm{l}$, $22 \cdot 8 \%$ showed over $2000 \mu \mathrm{g} / \mathrm{l}$, and $4.8 \%$ showed under $500 \mu \mathrm{g} / \mathrm{l}^{17}$ 
SUBJECTS

In 1987, 18 years after the closure of the mine, the addresses of 149 ex-miners were taken from lists of employees and the workers union, but 15 of them had already died. Finally, we were able to survey the health of 117 male workers, including ex-miners and workers in other job categories. After the closure of this mine, all of the ex-miners continued in employment. Some of them (seven miners) were transferred to another mercury mine and 22 moved to other mines in the same prefecture (11 to coal mines, nine to a copper mine, and two to a zinc mine). Those mines were also closed some years after the mercury mine was closed.

\section{HISTORY OF MERCURY INTOXICATION}

More than $70 \%$ of the 76 ex-miners with a history of mercury poisoning had inpatient care. Sixty three per cent of them were transferred from labour inside the pit to outside jobs. These transfers were recommended to decrease mercury exposure. The most frequent subjective symptoms were painful swelling of the gums (73.7\%), tremor of the hands or feet $(72 \cdot 4 \%)$, tiredness $(69 \cdot 7 \%)$, insomnia $(59 \cdot 2 \%)$, fatigue $(59 \cdot 2 \%)$, and irritability $(56 \cdot 6 \%) .^{18}$

\section{COMPARABILITY OF EXPOSED WORKERS AND} THEIR CONTROLS

The subgroup of 76 ex-mercury miners with a history of mercury poisoning during their employment in the mercury mine was compared with matched referents on the bases of age (within 3 years), sex, and education. Seventy six controls were selected from 154 residents who visited any of the seven municipal health centres located in the neighbourhood of the mercury mine for annual screening of chronic diseases.
Table 1 shows demographic characteristics of ex-miners with or without a history of mercury intoxication. Their mean age, education, duration of employment, time after exposure, and present mercury concentration in plasma, red blood cells, and urine were similar. The main difference between the two groups was in job categories. More than half of the workers with a history of mercury intoxication were engaged in mining or refining whereas only $14.6 \%$ of workers without a history of intoxication were employed in these two job categories.

A higher percentage of controls than exmercury mine workers were currently working, mainly because many of the controls over 60 years old were farmers. There were also some differences in the distribution of the job or industry categories, although there was no difference in the ratio of jobs involved in supervision, clerical work, and engineering.

\section{COLLECTION OF MEDICAL DATA AND TEST} PROCEDURES

Examination of the study group included (1) questionnaires on occupational and health histories, lifestyle habits including smoking, alcohol consumption, and food (such as the extent of fish consumption), subjective symptoms, and (2) neurobehavioural tests, clinical and neurological examinations, and biochemical tests of blood, liver, and kidney function. Detailed methods and results of the questionnaire survey were reported previously, ${ }^{18}$ and the results of the neurological examination were published elsewhere. ${ }^{19} 20$

\section{Subjective symptoms}

Questions dealing with chronic symptoms (n $=79$ ) included sensory disorders, psychiatric symptoms such as irritability, sleeping difficulties, impaired memory, and concentration

Table 1 Demographic data of ex-miners with and without a history of mercury intoxication

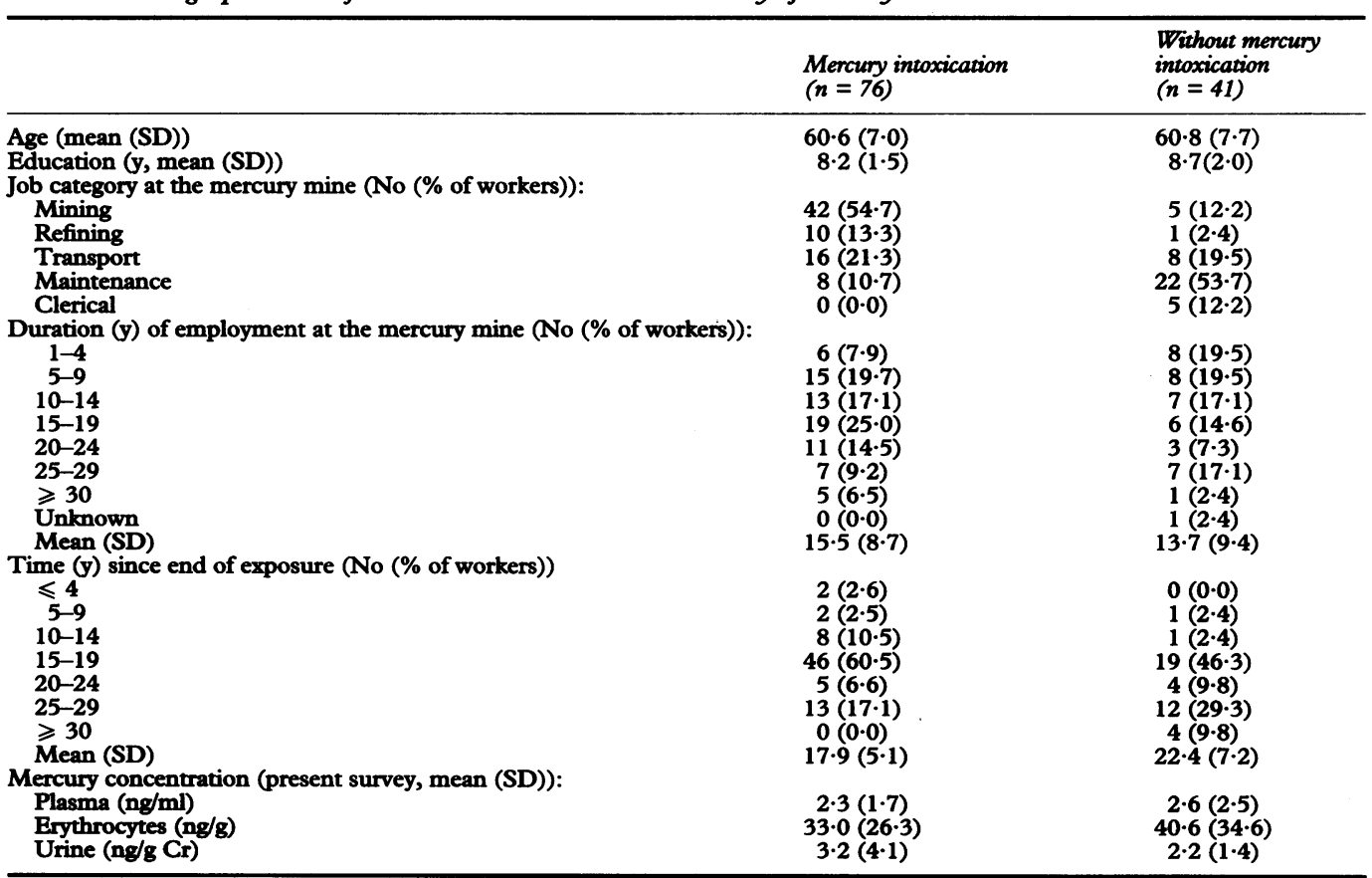


difficulties. Also, general symptoms, including those related to the autonomic nervous system, skin, and digestive system, as well as the cardiac respiratory system were included. We also included symptoms caused by mining work (such as respiratory dysfunction, lower back pain, hearing loss, and vibration syndrome) and geriatric symptoms (such as long sightedness, joint or lower back pain, and loss of sexual desire) mainly because the mean age of the ex-mercury miners was over 60 . The questions concerning chronic symptoms aimed to clarify whether they occurred in the past year or were present during employment at the mercury mine (or about 20 years ago for the controls).

\section{Measurements of mercury concentrations in blood and urine}

Mercury concentrations in blood and urine were measured by the heat decomposition gold amalgamation method, ${ }^{21}$ with Nippon Instruments MA-1S and D-2 at the time of the neurobehavioural study.

\section{Neurobehavioural evaluation}

The objective of the testing programme was to assess those residual effects of mercury exposure that were reported in previous studies. Tests were selected that could show defects in motor coordination, cognitive, and psychomotor function, and could be used under field conditions for the testing of elderly persons. The neurobehavioural examination consisted of an interview and a battery of tests that included (1) sensorimotor performance, '(2) psychomotor function, (3) handeye coordination, (4) reading fluency, (5) verbal and non-verbal cognition, and (6) short term memory.

Each subject was required to complete the following procedures.

\section{Sensorimotor performance}

Grip strength - Grip strength for both hands was determined with a hand dynamometer.

Equilibrium duration test-Subjects were asked to stand erect with one leg bent at the knee, both eyes shut, and arms outstretched. The test was performed three times and the mean endurance time was calculated.

Writing test-The writing test for hand tremor was the modified Bender Gestalt test. ${ }^{22}$ The reproduced figures were read blindly by one of us, unaware of the neurological state of the subjects. The sensitivity and specificity of this method were studied by Fukuda et al. ${ }^{22}$

\section{Psychomotor function}

Simple reaction time-The subject was required to grasp a falling steel pole as quickly as possible after a visual cue from the pole. $^{23}$

Tapping-Finger tapping is a motor speed task performed with a simple counter. The subject was asked to tap with his index finger as fast as possible. The whole task consists of 60 second trials with both hands.

Peg board and finger dexterity board-The subjects' task consisted of three different kinds of finger dexterity tests. The first test (replacement) was to replace as many sets of metal pegs in small round holes upside down as possible in 30 seconds. The task was performed with the preferred hand. In the second test a finger dexterity board was used and the subject was instructed to assemble rivets and washers with both hands and to use them to fill in as many holes as possible within the allotted time (90 seconds). In the third test (disjointing), the subject was asked to place the rivets on one side of a board and washers on a pole on the opposite side, separating as many of the sets as possible within $60 \mathrm{sec}-$ onds. These are standardised tests used by the Japan Ministry of Labour for vocational aptitude. ${ }^{24}$

\section{Hand-eye coordination}

The hand-eye coordination tests consisted of aiming (a motor coordination test published by the Tokyo University Department of Rehabilitation, Ueda, $1971^{25}$ ) and tracing (MacQuarrie ${ }^{26}$ ) tests, both the aiming and tracing test are paper and pencil tests that require a seated subject to aim at a centre point or trace a spiral pathway with a pencil. Fifty seconds were allowed for the completion of each test. The test score (error) was a function of the distance plotted from a centre and the number of times the edges of a concentric circle were touched with the pencil used for the aiming.

\section{Reading fluency}

Performance on the colour card reading test (Takei Instrument Co) was assessed in terms of word reading speed, and reading fluency. ${ }^{27}$ The colour card had five colour strips (red, blue, yellow, black, and white), printed on a grey board and was set in a $10 \times 10$ matrix; each colour strip appeared 20 times. The instructions stressed the need for both speed and accuracy.

\section{Verbal and non-verbal cognition}

Kohs block design test-Kohs block design ${ }^{28}$ is a test for visual ability - namely, the ability to see and reproduce spatial relations. The subject was given four or nine two coloured blocks. The test includes 10 items and it becomes more difficult from item to item.

Hasegawa's dementia screening scale ${ }^{29}$-This is composed of 11 questions: (a) five primitive questions about date, name of the place, age, birthplace, and time, (b) two intelligence tests about the year of the end of the second world war and the name of the prime minister, (c) one series involving calculations, such as subtract seven from 100 , then seven from 93, (d) digit span-that is, to name numbers in reverse-for example, 6-8-2, 3-5-2-9, (e) immediate visual memory-namely, to list five things (coin, toothbrush, watch, comb, and spoon) and recall them. There are 
scoring norms for normal, borderline, predementia, and dementia.

\section{Short term memory}

Short term memory was assessed by the digit span test (WAIS) ${ }^{30}$; the test score was the total number of digits correctly repeated forward and backward.

\section{STATISTICAL METHODS}

The prevalence rates of diseases experienced by ex-mercury miners and controls were compared by odds ratios with $95 \%$ confidence intervals (95\% CIs) according to McNemar. ${ }^{31} \mathrm{p}$ Values were calculated by $\chi^{2}$ statistics. Differences in the neuropsychological performances of the exposed workers and the non-exposed matched controls were estimated with one tailed $t$ tests for unpaired data.

Careful assessment of potential confounding variables is essential for the proper epidemiological evaluation of neurobehavioural effects. It is important, for example, to examine the nature of the relation between neurobehavioural functions and age, alcohol and drug intake, education, and other variables that may influence a person's state of performance. ${ }^{32}$ Multiple regression analysis ${ }^{33}$ was used to investigate the relation between exposure to mercury and both symptoms and neurobehavioural function while controlling for these potential confounding factors. The backward elimination technique was used, whereby all variables were entered into the equation, then sequentially removed if the probability of its $\mathrm{F}$ value was $>0.05$.

The suspected interaction between age and history of mercury intoxication was also investigated in the regression models by including the product of the subject's age and the presence or absence of a history of mercury intoxication.

\section{Results}

MERCURY CONCENTRATIONS IN BIOLOGICAL SAMPLES

Mean mercury concentrations of examiners with a history of mercury intoxication were, in plasma $2.3 \mathrm{ng} / \mathrm{ml}$, in red blood cells $33.0 \mathrm{ng} / \mathrm{g}$, and in urine $3.2 \mathrm{ng} / \mathrm{g}$ creatinine (table 1). The concentrations were similar to those of ex-miners without mercury intoxication and to those of healthy men living in Japan. ${ }^{34}$

\section{PREVALENCE OF DISEASES}

Table 2 shows diseases experienced among ex-mercury miners with mercury toxicosis and their controls. The prevalences of hypertension, lower back pain, and pneumoconiosis among ex-miners with a history of mercury poisoning were significantly higher than among their controls. There were some increases in the prevalences of haemorrhoids and neuritis among ex-mercury miners, but those were not significant.

\section{SUBJECTIVE SYMPTOMS}

Detailed results on symptoms were presented in our previous report. ${ }^{18}$ Briefly, the symptoms more often experienced during employment at the mine rather than at present were tremors of hands, feet, and fingers, painful swelling of the gums, and central nervous system symptoms such as irritability and depression, which were termed erethism. By contrast, the symptoms more often experienced at present were geriatric symptoms such as long sightedness, decline in sexual desire, pain in the joints, back or hips, and frequent sputum and coughing. Although the extent of the symptoms of ex-workers caused by mercury poisoning decreased considerably after the end of exposure, comparison between the exposed workers and the controls showed that the prevalence of neurological symptoms (such as hand tremors, headache, and slurred speech), those associated with mining work (such as symptoms related to pneumoconiosis and lower back pain), and geriatric symptoms were significantly higher than in the group of controls.

Table 3 shows a summary of stepwise backward regression analyses of subjective symptoms. Some exposure variables, duration of exposure, job categories classified by the exposure to mercury based on the data by Hashiba, ${ }^{16}$ and the number of hospital admissions for inpatient care had a significant positive relation with the increase in symptoms of the nervous system both during employment and within the past year. Respiratory

Table 2 Prevalence of diseases in the ex-mercury miners with a history of mercury poisoning and their matched referents (76 pairs)

\begin{tabular}{|c|c|c|c|c|}
\hline Disease & $\begin{array}{l}\text { Ex-miners } \\
(\%)\end{array}$ & $\begin{array}{l}\text { Referents } \\
(\%)\end{array}$ & $\begin{array}{l}\text { Odds }(95 \% \text { CI }) \\
\text { ratio }\end{array}$ & $\begin{array}{l}p \text { Value } \\
\left.\text { (from } \chi^{2}\right)\end{array}$ \\
\hline $\begin{array}{l}\text { Hypertension } \\
\text { Lower back pain } \\
\text { Diabetes mellitus } \\
\text { Neuritis } \\
\text { Pneumoconiosis } \\
\text { Gastric ulcer } \\
\text { Haemorrhoids } \\
\text { Liver disease } \\
\text { Coronary heart disease } \\
\text { Artherosclerosis } \\
\text { Nephritis } \\
\text { Cerebral contusion } \\
\text { Psychosis } \\
\text { Stroke } \\
\text { Gall stones } \\
\text { Cancer }\end{array}$ & $\begin{array}{r}32 \cdot 9 \\
21 \cdot 1 \\
14 \cdot 5 \\
13 \cdot 2 \\
10 \cdot 5 \\
9 \cdot 2 \\
7 \cdot 9 \\
3.9 \\
6 \cdot 6 \\
6 \cdot 6 \\
3.9 \\
3.9 \\
2 \cdot 6 \\
1.3 \\
0.0 \\
0.0\end{array}$ & $\begin{array}{r}18 \cdot 4 \\
6 \cdot 6 \\
13 \cdot 2 \\
5 \cdot 3 \\
0 \cdot 0 \\
6 \cdot 6 \\
2 \cdot 6 \\
7 \cdot 9 \\
6 \cdot 6 \\
5 \cdot 3 \\
0 \cdot 0 \\
0 \cdot 0 \\
0 \cdot 0 \\
0 \cdot 0 \\
2 \cdot 6 \\
0 \cdot 0\end{array}$ & 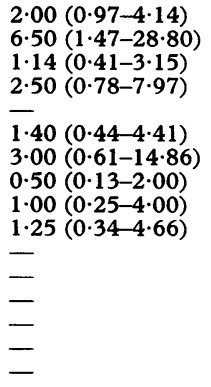 & $\begin{array}{l}<0 \cdot 005 \\
<0 \cdot 001 \\
\text { NS } \\
<0 \cdot 1 \\
<0 \cdot 001 \\
\text { NS } \\
\text { NS } \\
\text { NS } \\
\text { NS } \\
\text { NS } \\
\text { NS } \\
\text { NS } \\
\text { NS } \\
\text { NS } \\
\text { NS } \\
\text { NS }\end{array}$ \\
\hline
\end{tabular}


Table 3 Summary of stepwise backward linear regression analyses of subjective symptoms (117 ex-miners)

\begin{tabular}{|c|c|c|c|c|c|c|c|}
\hline \multirow[b]{2}{*}{ Variables } & \multicolumn{4}{|c|}{ Symptoms during employment } & \multicolumn{3}{|c|}{ Symptoms within the past year } \\
\hline & $\begin{array}{l}\text { Nervous } \\
\text { system }\end{array}$ & Psychiatric & Teeth & $\begin{array}{l}\text { Digestive } \\
\text { system }\end{array}$ & $\begin{array}{l}\text { Nervous } \\
\text { system }\end{array}$ & Geriatric & $\begin{array}{l}\text { Respiratory } \\
\text { system }\end{array}$ \\
\hline Duration of exposure (y) & & & & $-(0.02)$ & $+(0.04)$ & & \\
\hline Job exposure category & $+(0.001)$ & & & $+(0.04)$ & $+(0.04)$ & & $+(0.021)$ \\
\hline Inpatient care & $\begin{array}{l}+(0.001) \\
+(0.000)\end{array}$ & & $+(0.000)$ & $+(0.000)$ & & & \\
\hline $\begin{array}{l}\text { (frequency) } \\
\text { Job transfer }\end{array}$ & & $+(0.000)$ & & & & & \\
\hline (frequency) & & & & & & & \\
\hline $\begin{array}{l}\text { Alcohol intake } \\
\text { (frequency) }\end{array}$ & $-(0.04)$ & $-(0.04)$ & & & $-(0.008)$ & & \\
\hline $\begin{array}{l}\text { Gastric ulcer } \\
\text { Neuritis }\end{array}$ & & & & & $\begin{array}{l}+(0.000) \\
+(0.001)\end{array}$ & $\begin{array}{l}+(0.026) \\
+(0.000)\end{array}$ & $\begin{array}{l}+(0.004) \\
+(0.11)\end{array}$ \\
\hline & 0.45 & $0 \cdot 21$ & $0 \cdot 17$ & $0 \cdot 15$ & 0.25 & $0 \cdot 15$ & 0.11 \\
\hline
\end{tabular}

and neuritis were scored $0=$ no, $1=$ yes; age, education, smoking, history of hypertension, and diabetus mellitus were NS.

symptoms also had a positive association with job categories, mainly because considerable numbers of ex-pit workers suffered pneumoconiosis in this mine (table 2). The ex-miners who consumed alcohol more often, complained less of nervous system and psychiatric symptoms than the ex-miners who consumed alcohol less often.

NEUROBEHAVIOURAL COMPARISON BETWEEN THE EXPOSED WORKERS AND CONTROLS

Matched paired analysis showed that grip strength, simple reaction time, performance of tapping, finger dexterity, hand-eye coordi-

Table 4 Mean performance (SD) on neuropsychological tests by ex-workers with histories of mercury toxicosis and matched referents

\begin{tabular}{|c|c|c|c|}
\hline Performance & Ex-workers & Referents & p Value \\
\hline $\begin{array}{l}\text { Height } \\
\text { Weight }\end{array}$ & $\begin{array}{r}162 \cdot 5(4 \cdot 2) \\
60 \cdot 5(6 \cdot 6)\end{array}$ & $\begin{array}{c}160.4(5 \cdot 5) \\
60.3(10 \cdot 0)\end{array}$ & $\stackrel{\star}{\star \star}$ NS \\
\hline $\begin{array}{l}\text { Grip strength: } \\
\text { Right } \\
\text { Left } \\
\text { Romberg }\end{array}$ & $\begin{array}{r}37.6(7.3) \\
37.6(7.1) \\
1.2(0.5)\end{array}$ & $\begin{array}{r}41.8(6.7) \\
39.8(6.3) \\
1.1(0.3)\end{array}$ & $\begin{array}{l}\star \star \\
\star \\
\text { NS }\end{array}$ \\
\hline $\begin{array}{c}\text { Equilibrium } \\
\text { duration }\end{array}$ & $14 \cdot 0(1 \cdot 3)$ & $12 \cdot 4(13 \cdot 7)$ & NS \\
\hline $\begin{array}{l}\text { Tremor } \\
\text { (Bender Gestalt) }\end{array}$ & $2.5(1.3)$ & $2 \cdot 3(0 \cdot 7)$ & NS \\
\hline $\begin{array}{l}\text { Simple reaction } \\
\text { time }\end{array}$ & $228 \cdot 6(24 \cdot 7)$ & $216.7(31 \cdot 8)$ & $\star \star$ \\
\hline $\begin{array}{c}\text { Tapping: } \\
30 \mathrm{~s} \\
60 \mathrm{~s}\end{array}$ & $\begin{array}{l}147 \cdot 1(27 \cdot 6) \\
287 \cdot 9(50 \cdot 8)\end{array}$ & $\begin{array}{l}159.0(31.6) \\
308.4(55.6)\end{array}$ & $\stackrel{\star \star}{\star}$ \\
\hline $\begin{array}{l}\text { Peg board and } \\
\text { finger dexterity } \\
\text { board: } \\
\text { Replacement } \\
\text { Assemblage } \\
\text { Disjointing }\end{array}$ & $\begin{array}{l}19 \cdot 2(4 \cdot 2) \\
22 \cdot 4(5 \cdot 0) \\
17 \cdot 7(4 \cdot 2)\end{array}$ & $\begin{array}{l}21 \cdot 2(4 \cdot 5) \\
23 \cdot 4(4 \cdot 4) \\
19 \cdot 4(4 \cdot 2)\end{array}$ & $\stackrel{N \star}{N S}$ \\
\hline $\begin{array}{l}\text { Hand eye } \\
\text { coordination: } \\
\text { Aiming } \\
\text { Error, right } \\
\text { Error, left } \\
\text { Tracing }\end{array}$ & $\begin{array}{c}3 \cdot 6(4 \cdot 3) \\
11 \cdot 0(11 \cdot 0) \\
38 \cdot 2(14 \cdot 8)\end{array}$ & $\begin{array}{c}3.0(6 \cdot 7) \\
5.4(6.5) \\
48 \cdot 3(18 \cdot 5)\end{array}$ & $\underset{\substack{\star \star \star \star \\
\star \star \star}}{N S}$ \\
\hline $\begin{array}{l}\text { Colour card Readin } \\
\text { Time } \\
\text { Error } \\
\text { Block design }\end{array}$ & $\begin{array}{l}\text { ng: } \\
79.6(22.1) \\
0.5(0.9) \\
37.0(15.5)\end{array}$ & $\begin{array}{c}72 \cdot 3(18 \cdot 0) \\
0.4(1 \cdot 0) \\
43.9(18 \cdot 2)\end{array}$ & $\underset{\star \star}{\star}$ \\
\hline $\begin{array}{l}\text { Digit span: } \\
\text { Forward } \\
\text { Backward } \\
\text { Dementia scale }\end{array}$ & $\begin{array}{r}4.9(1.1) \\
3.5(0.8) \\
28.9(3.0)\end{array}$ & $\begin{array}{r}5.5(1.1) \\
3.0(0.9) \\
29.7(2.9)\end{array}$ & $\begin{array}{l}\star \star \star \\
\text { NS } \\
\text { NS }\end{array}$ \\
\hline
\end{tabular}

${ }^{\star} \mathrm{p}<0.05$ (one tailed); ${ }^{\star \star} \mathrm{p}<0.01 ;{ }^{\star \star \star} \mathrm{p}<0.001$. nation, speed of colour card reading, the block design test, and the short term memory (digit span) showed significant deterioration compared with controls (table 4).

\section{RELATION BETWEEN NEUROBEHAVIOURAL PERFORMANCE AND HISTORY OF MERCURY EXPOSURE}

Multiple linear regression analysis showed significant relations between the duration of exposure and poor performance of hand eye coordination (aiming), tapping, and colour card reading. Job categories classified by exposure to mercury also had significant negative relations with these performances. The period of years after the end of exposure was significantly correlated with better performances of reaction time and digit span. On the other hand, a history of mercury intoxication itself had no significant relation with any of the current neurobehavioural performances. Current working state ( 1 , working; 0 , not working) had significant positive relations with grip strength, hand-eye coordination (tracing), reaction time, tapping, and colour card reading. No significant correlations were found with education or frequency of alcohol intake. Some variables-namely, equilibrium duration test, psychomotor performance (pegboard) and Kohs block design test showed poorer performance with increasing age (table 5).

Also the interaction term of age $\times$ history of mercury intoxication ${ }^{33}$ showed a significant correlation with deteriorating performance of hand eye coordination (aiming), pegboard, and block design test (table 5). Most subjects showed poorer performance with increasing age. For several measures, subjects with previous mercury toxicosis showed more pronounced age related trends toward deteriorating performance than did control subjects and ex-mercury miners without a history of mercury toxicosis. The figure shows the age $\times$ mercury toxicosis interaction for the performance of aiming. Thus, subjects 65 years of age and older showed the most significant differences between those with and without histories of mercury poisoning and control subjects. 
Table 5 Summary of stepwise backward linear regression analysis of neurobehavioural tests (117 ex-workers)

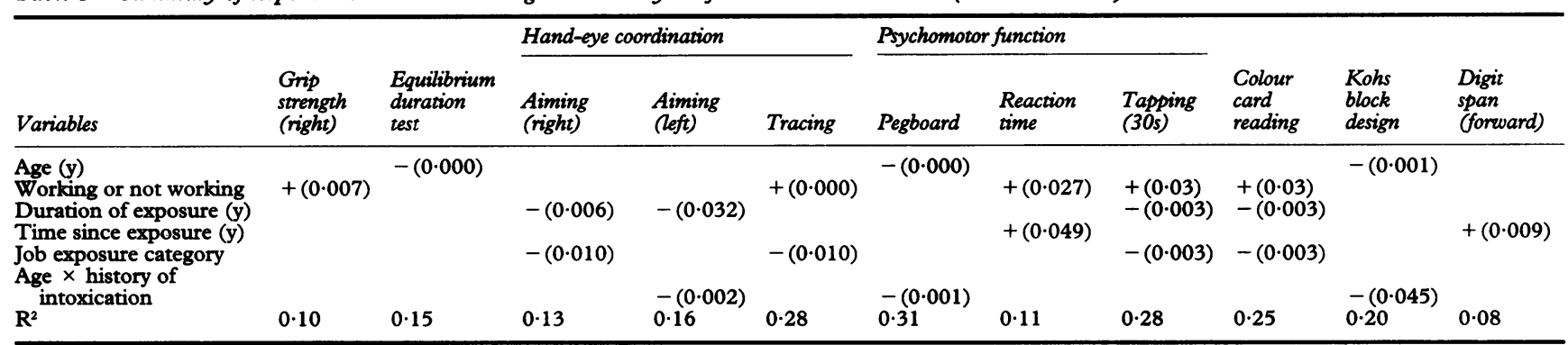

+ or $-(p$ value $)=$ increase or decrease in function $(p<0.05$ only); working or not working, and job exposure category were scored $0=$ no, $1=$ yes; history of intoxication, education, and frequency of alcohol intake were NS.

Interaction of age and performance of aiming for miners with and without mercury intoxication and controls.

\section{Discussion}

It is a well recognised fact that chronic exposure to mercury can result in complex alterations of a person's physiological state with the primary effects being in the central nervous system. Tremors and erethism are especially emphasised. ${ }^{35}$ Deficiencies in short term memory and verbal intelligence tests have been also detected among chlorine alkali workers 9 and workers at a fluorescent lamp factory ${ }^{10}$ exposed to low concentrations of mercury, whereas patients suffering from

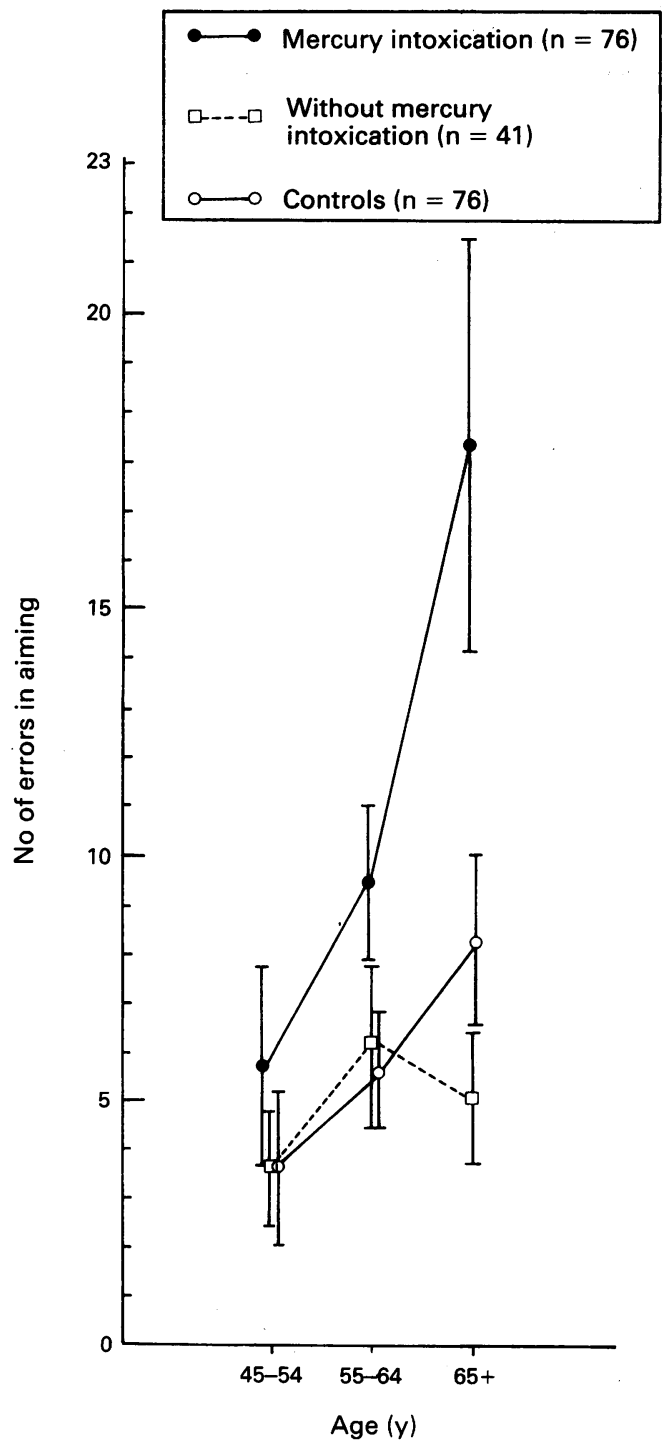

advanced mercury intoxication have had other neurological problems, such as constricted visual fields and disorders of the auditory nerve. ${ }^{35}$

It is not so easy, however, to determine if there were any residual effects of long term exposure to mercury vapour from the present results, because exposure related neurological dysfunction caused by mercury vapour is often reversible, ${ }^{36}$ and only rarely is the toxic exposure so massive or the neuronal target so vulnerable that irreversible neuronal changes ensue. The ex-miners in this study had been working under conditions in which the mercury concentrations of the atmosphere were almost 100 times higher than the current threshold limit value $\left(0.05 \mathrm{mg} / \mathrm{m}^{3}\right)$ in Japan. Many of the ex-miners mentioned that they suffered from mercury poisoning so often that they could not remember exactly how many times they required inpatient care. Takahata et $a l^{37}$ studied two necropsy cases who had worked for about 10 years in the same mercury mine and had also worked as pit workers in other mines, including coal, gold, sulphur, and asbestos. Both cases showed residual effects of mercury exposure-namely, rough tremors and ataxia even 10 years after the end of exposure to mercury vapour. The mercury concentrations in the brains of the two cases were high, especially in the occipital cortex (33.56 and $14.80 \mathrm{ppm})$, parietal cortex (6.21 and $13.80 \mathrm{ppm}$ ) and the substantia nigra (23.05 and $18.00 \mathrm{ppm}$ ), although histopathologically no specific changes were found except electron dense granules in the cytoplasm of nerve cells, particularly Purkinje cells.

From an epidemiological viewpoint, it was difficult to find proper controls for our exworkers, because of their age and the fact that they had compulsory transfers to several jobs after the closure of the mine. Although we tried to find matched controls with the same educational attainment, age, sex, and residency, the occupational histories of the controls were not exactly in the same category as those of ex-miners. Thus we applied multiple linear regression models for all ex-mercury mine workers to clarify the effects of these confounding factors. Based on this analysis there are slight but persistent effects on neurobehavioural function, especially on motor coordination among mercury miners even more than 15 years after the end of exposure. Multiple regression analysis indicates that the 
effects of chronic mercury toxicity found after the end of exposure correlates with the duration of exposure, period after the end of exposure, and job categories. There was also an interaction between age and the history of intoxication.

Our results agree well with the study by Albers et al. ${ }^{15}$ They found that ex-workers with high mercury exposure during their employment still showed significantly decreased strength, decreased coordination, increased tremors, decreased sensation, and increased prevalence of Babinski and snout reflexes when compared with control subjects, even 20 to 25 years after the end of exposure. Further follow up studies on the neurobehavioural function of ex-mercury workers are needed to confirm how long the residual effects of chronic mercury exposure after the end of exposure last. Longitudinal follow up studies on the interaction of aging and mercury toxicosis seem to be especially important, as natural neuronal attrition may enhance the subclinical performance decrements related to previous mercury exposure.

There were some significant relations among symptoms and exposure and other related variables according to the multivariate analysis. Alcohol intake decreased both nervous system and psychiatric symptoms during employment and within the past year. Two reasons may cause such a significant correlation. Firstly, alcohol intake influences the retention and exhalation of $\mathrm{Hg} .{ }^{38} 39$ Secondly, alcohol may decrease the rate of oxidation of mercury vapour. ${ }^{40}$

This study was supported by Toyota Foundation Contract 87-111-026 entitled "a comprehensive study of ex-miners who formerly worked in a mercury mine by social and medical evaluation." The time, effort, and support of many persons who used to work at Itomuka mercury mine enabled this study to be successfully completed. We specifically acknowledge the support of $\mathrm{Mr}$ Y Tsuchiya and S Endoh and the staff of the Kitami Municipal Health Center.

1 Bidstrup PL. Toxicity of mercury and its compounds. Amsterdam: Elsevier, 1964

2 Miller J, Chaffin DB, Smith RG. Subclinical psychomotor and neuromuscular changes in workers exposed to
organic mercury. Am Ind Hyg Assoc $\mathcal{F} 1975 ; 36: 725-33$.

3 Langolf GD, Chaffin DB, Henderson R, Whittle HP. Evaluation of workers exposed to elemental mercury Evaluation of workers exposed to elemental mercury
using quantitative tests of tremor and neuromuscular using quantitative tests of tremor and neurom
functions. $A m$ Ind Hyg $A$ ssoc $\mathcal{7} 1978 ; 39: 976-84$.

4 Fawer RF, Ribaupierre Y, Guillemin MP, Berode M, Lob $M$. Measurement of hand tremor induced by industrial exposure to metallic mercury. $B r \mathcal{F}$ Ind Med 1983;40: 204-8.

5 Forzi M, Cassitto MG, Bulgheroni C, Foa V. Psychological measures in workers occupationally exposed to mercury vapors; a validation study. In: $M$ Horvath, ed. Adverse effects of environmental chemicals
and psychotropic drugs. vol 2. Amsterdam: Elsevier, 1976:165-71.

6 Williamson AM, Teo RKC, Sanderson J. Occupational mercury exposure and its consequences for behavior. Int Arch Occup Environ Health 1983;50:165-71.

7 Smith PJ, Langolf G, Goldberg J. Effects of occupational exposure to elemental mercury on short term memory.
$B r$ f Ind Med 1983;40:413-9.

8 Piikivi L, Hanninen H, Martelin T, Mantere P. Psychological performance and long-term exposure to mercury vapors. Scand $\mathcal{F}$ Work Environ Health 1984;10: 35-41.

9 Piikivi L, Hanninen H. Subjective symptoms and psychological performance of chlorine-alkali workers. Scand $\mathcal{F}$ Work Environ Health 1989;15:69-74.

10 Soleo L, Urbano ML, Petrera V, Ambrosi L. Effects of low exposure to inorganic mercury on psychological performance. Br F Ind Med 1990;47:105-9.

11 Gilioli R, Bulgheroni C, Caimi L, Foa V. Correlations between subjective complaints and objective neurophysiological findings in workers of a chlor-alkali plant. In:
M Horvath ed. Adverse effects of environmental chemicals and psychotropic drugs. vol 2. Amsterdam: Elsevier, 1976:157-64.

12 Levine SP, Cavender GD, Langolf GD, Albers JW. Elemental mercury exposure: peripheral neurotoxicity. Br 7 Ind Med 1982;39:136-9.

13 Albers, JW, Cavender GD, Levine SP, Langolf GD. Asymptomatic sensorimotor polyneuropathy in workers exposed to elemental mercury. Neurology 1982;32: 1168-74.

14 Singer R, Valciukas JA, Rosenman KD. Peripheral neurotoxicity in workers exposed to inorganic mercury compounds. Arch Environ Health 1987;42:181-4.

15 Albers JW, Kallenbach LB, Fine LJ, Langolf GD, Wolfe RA, Donofrio PD, et al, and Mercury Workers Study Group. Neurological abnormalities associated with remote occupational elemental mercury exposure. Ann Neurol 1988;24:651-9.

16 Hashiba T. A research on the mercury poisoning of miners (Report No 1-5). Hokkaidolgaku Zasshi 1954; 29:282-341. (In Japanese.)

17 Suwa N, Takahata N. Clinical studies of chronic inorganic mercury poisoning. Recent Advances in Research

18 Kishi R, Doi R, Fukuchi Y, Satoh H, Satoh T, Ono A, Moriwaka F, Tashiro K, Takahata N, and the Mercury Workers Study Group. Subjective symptoms and neurobehavioral performances of ex-mercury miners at an robehavioral performances of ex-mercury miners at an average of 18 years after the cessation of chronic expotional symposium on neurobehavioral methods and effects in tional symposium on neurobehavioral methods and effects in occupational and environmental heat

19 Tashiro K, Moriwaka F, Doi R, Satoh H, Fukuchi Y, Kishi R, Hamada T, Shima $\mathrm{K}$. Motor neuron disease and mercury content. In: Mannenn Tohru ed. Annual report of the research committee of CNS degenerative diseases. Tokyo: Ministry of Heald

20 Moriwaka F, Tashiro K, Doi R, Satoh H, Fukuchi Y. A clinical evaluation of the inorganic mercurialism-its pathogenic relation to amyotrophic lateral sclerosis. Clin Neurol 1991;31:885-7. (In Japanese.)

21 Satoh $\mathrm{H}$. From the experience of the mercury analyses on biological samples. Biomedical Research into Trace Elements 1992;3:61-2.

22 Fukuda K, Sanada H, Takekawa T, Miyake H. Screening for hand tremor by a modified Bender Gestalt test. fapanese foumal of Industrial Health 1975;17:149-53.

23 Ohnishi T. Measurement of physical activity. In: Miura T, ed. Handbook of industrial hygiene, new ed. Tokyo: Institute Labor Science, 1974:475. (In Japanese.)

24 Japan Ministry of Labor. Manual of tests for vocational aptitude. Tokyo: Japan Ministry of Labor, 1969.

25 Ueda S. Rehabilitation in medicine. Tokyo: Tokyo University Press, 1971:32. (In Japanese.)

26 MacQuarrie TW. MacQuarrie test for mechanical ability. Monterey: California Test Bureau, 1953.

27 Karino H. Blocking test. In: Miura T, ed. Handbook of industrial hygiene, new ed. Tokyo: Institute Labor industrial hygiene, new ed. To
Science, 1975;650. (In Japanese.)

28 Kohs SC. The block design tests. F Exp Psychol 1920;3: 357-76.

29 Hasegawa K. Hasegawa dementia screening scale, source of geriatric assessment, vol 2. In: Israel $\mathrm{L}$, $e t$ al, eds. Review of analyzed instruments. Karger, 1984.

30. Wechsler D. Wechsler adult intelligence scale manual. Tokyo: Psychological Corporation, 1955.

31 McNemar Q. Note on sampling error of the difference between correlated proportions of percentage. Psychometrika 1947;12:153-7.

32 Johnson BL. Prevention of neurotoxic illness in working populations. Chichester: Wiley and Sons, 1987.

33 Kleinbaum DG, Kupper LL; Muller KE. Applied regression analysis and other multivariable methods. Boston: Pion analysis and

34 Yamamura Y, Yoshinaga Y, Arai F, Kishimoto T, Aoyama H, Yamamura S. Normal concentrations of total mercury in human blood and urine. Fapanese total mercury in human blood and

35 Kark RAP. Clinical and neurochemical aspects of inorganic mercury intoxication. In: Vinken $P$, Bruyn $G$, ed. Handhook of clinical neurology: vol 36. New York: Elsevier/North-Holland Biochemical Press, 1979: 147-97.

36 Kishi R, Hashimoto $K$, Shimizu S, Kobayashi $M$. Behavioral changes and mercury concentrations in tissues of rats exposed to mercury vapor. Toxicol Appl Pharmacol 1978:46:555-66.

37 Takahata $\mathrm{N}$, Hayashi $\mathrm{H}$, Watanabe $\mathrm{S}$, Anso $\mathrm{T}$. Accumulation of mercury in the brains of two autopsy Accumulation of mercury in the brains of two autopsy Psychiatrica et Neurol fap 1970;24:59-69.

38 Nielsen-Kudsk F. The influence of ethyl alcohol on the absorption of mercury vapor from the lungs in man. absorption of mercury vapor from the

39 Hursh JB, Greenwood MR, Clarkson TW, Allen J, Demuth $S$. The effects of ethanol on the fate of mercury Demuth $S$. The effects of ethanol on the fate of mercury
vapor inhaled by Man. $f$ Pharmacol Exp Ther vapor inhaled

40 Magos L, Clarkson TW, Greenwood MR. The depression of pulmonary retention of mercury vapor by ethanol: identification of the site of action. Toxicol Appl Pharmacol 1973;26:180-3. 